Safety nets or straitjackets?

Regulating working time in the Danish, German and American metal industries

Ilsøe, Anna

Published in:

European Journal of Industrial Relations

DOI:

10.1177/0959680111430563

Publication date:

2012

Document version

Peer reviewed version

Citation for published version (APA):

Ilsøe, A. (2012). Safety nets or straitjackets? Regulating working time in the Danish, German and American metal industries. European Journal of Industrial Relations, 18(1), 37-51.

https://doi.org/10.1177/0959680111430563 


\title{
Safety nets or straitjackets? Regulating working time in the Danish, German and American metal industries
}

\author{
Anna llsøe \\ Copenhagen University, Denmark
}

\begin{abstract}
Does regulation of working hours at national and sector level impose straitjackets, or offer safety nets to employees seeking working-time flexibility? This article compares legislation and collective agreements in the metal industries of Denmark, Germany and the USA. The industry has historically been trend-setting for collective bargaining in all three countries, but with very different effects on working time. Organized decentralization seems to pave the way for fewer straitjackets, whereas the opposite seems to be the case with regard to disorganized decentralization.
\end{abstract}

\section{Keywords}

working time, industrial relations, decentralization, metal industry, Denmark, Germany, USA 


\section{Introduction}

In recent years, flexible working hours have offered a platform for new compromises between employers and employees at the workplace. Employers have pushed for the decentralization of collective bargaining on working hours to increase local competitiveness, whereas employees have called for more flexible scheduling of hours to balance their work and family life (Katz, 1993; Marginson and Sisson, 2004).

However, important challenges remain. National regulatory frameworks offer differing room for manoeuvre. In some countries, legislation and/or sectoral agreements on working hours are highly prescriptive and leave little room for variation at company level, imposing 'straitjackets' on working-time flexibility. In others, national regulation is less binding and leaves more room for negotiation at company level. This can facilitate family-friendly working hours, but only if employees possess substantial bargaining power. If employees cannot exert effective influence over local management, they will be better off with more rigid national regulation. However, this does not necessarily mean a very detailed regulation of working hours. We also find examples of labour market regulation defining minimum standards, which offer employees a 'safety net'. It is an empirical question whether or not such safety nets impose straitjackets. Even minimum standards which lack detailed content may still prescribe rules that work against the wishes of certain groups of employees.

This article examines the effects of regulatory frameworks on working hours in Denmark, Germany and the USA, in terms of their level of detail (safety nets) and degree of completeness (straitjackets). All three countries have seen decentralization of collective bargaining; but in Denmark --- a case of organized decentralization --- this has not caused a significant decline in union density and collective agreement coverage, whereas disorganized decentralization in the USA has been associated with such a decline. Germany falls between the two: what started out as organized decentralization more and more resembles disorganized decentralization. These differences have had a significant influence on the regulation of working hours. When union density falls, employees lose significant bargaining power at company level, and unions might see it as impossible to avoid straitjackets on working hours without losing important safety nets at the same time.

To limit the scope of analysis, I focus on the regulation of flexitime, the type of flexible working hours most requested by employees. I also focus on the metal industry, which has been trend-setting in the decentralization of collective bargaining in all three countries. The next section describes the methods and data used in the comparative analysis. I then present some general trends in flexible working hours and decentralization of collective bargaining in the three countries. This is followed by detailed analysis of the regulation of working hours in each of the three countries. Finally, the three cases are compared and the results are discussed. 


\section{Methods and data}

The study is primarily based on an analysis of academic literature and survey data from the three countries. In particular two surveys are used, the European Social Survey 2004 and the US Current Population Survey 2004, as they ask relevant questions in similar ways, present population-wide data and were conducted in the same year. Other relevant but less comparable survey data are used to support the analysis. I also draw on a number of background interviews with leading representatives of trade unions, employers' organizations and lobbying groups covering the metal industry in Germany and Denmark (2005-06) and the USA (2007).

\section{General trends in flexible working hours and decentralization of collective bargaining}

Working time has always been a core issue of collective bargaining. However, the content and character of bargaining on working hours have changed dramatically within the last two decades. First, the focus has shifted from negotiating the weekly number of working hours to its timing (Marginson and Sisson, 2004; Seifert, 2005). Employers have increasingly seen flexible working hours as a means to increase productivity and make better use of new work organization, whereas employees have asked for more flexibility to obtain a better work-life balance (Bosch, 2001; Katz, 1993). Flexitime, the focus of this article --- flexible working time arrangement that (within limits) allow employees to vary their start and finishing times to fit their obligations outside work --- has in particular attracted employees. However, flexitime arrangements can also be attractive for employers who seek to recruit or retain employees with small children or other care responsibilities (Ilsøe, 2010; Wilson, 2001).

Roughly half of employees in Denmark and Germany, in both public and private sectors, have access to flexitime, and about a quarter in the USA (see Table 1). The proportions are similar in manufacturing (which includes the metal industry). Flexitime is often implemented via personal time accounts, whereby employees can save up surplus hours and later spend them as time off in lieu. It usually involves increased employee influence over daily working hours and is often seen as an instrument to improve work-life balance (Deding et al., 2006; Golden, 2001; Presser, 2006). This contrasts with other forms of flexible working hours such annualized hours, where the timing of work is controlled by management (Arrowsmith, 2007). However, a number of studies have also questioned the level of employee influence in the implementation of flexitime. In some cases management can be reluctant to give up control (Ilsøe, 2010), whereas in other cases employees are unable to make use of flexitime because of heavy workloads (Lewis and Dulk, 2010). This suggests that flexitime is no guarantee of increased employee influence over daily working hours. 


\begin{tabular}{|c|c|c|c|c|}
\hline & All sectors & Public & $\begin{array}{l}\text { Private } \\
\text { All }\end{array}$ & Manufacturing \\
\hline $\begin{array}{l}\text { Denmark } \\
\text { Germany } \\
\text { USA }\end{array}$ & $\begin{array}{l}52 \\
46 \\
28\end{array}$ & $\begin{array}{l}41 \\
47 \\
20\end{array}$ & $\begin{array}{l}49 \\
46 \\
29\end{array}$ & $\begin{array}{l}48 \\
52 \\
24\end{array}$ \\
\hline
\end{tabular}

Source: European figures from the European Social Survey 2004; US figures from the Current Population Survey 2004 (BLS, 2005a).

Second, in line with demands for more flexibility, in many countries bargaining over working hours has been delegated from sectoral to company level. Indeed, the need to adapt working time to new forms of work organization has been a driver of the overall decentralization process (Katz, 1993), as employers push for local negotiations of hours to adjust work schedules to the changing needs of production. Unions have been more hesitant about decentralization of collective bargaining on working hours, even though local negotiations could also facilitate adjustment of work schedules to specific employee needs. For workers as well as employers to benefit from local bargaining over working hours, they need sufficient bargaining power. In countries characterized by disorganized decentralization, low union densities and poor coverage of collective agreements make it difficult for employees to articulate their needs (Traxler, 1995; Visser, 2006). Accordingly, unions can be reluctant to give up regulatory control of working time. This is the case in the USA, where we find a union density of 12 percent in manufacturing and only 7 percent in the private sector as a whole. The coverage of collective bargaining is only marginally higher than the union density (BLS, 2005b). Such workers have little bargaining power at company level. Furthermore, if agreements are concluded, they are concluded at company level: disorganized decentralization does not indicate a move from a multi-employer to single-employer bargaining, as the latter has always predominated, but rather a fall in union density accompanied by a loss of horizontal coordination of company bargaining. This is especially true in the metal industry, where previously strong pattern bargaining has weakened in recent years (Kochan et al., 1994; Traxler, 1995).

One would expect unions to be more willing to delegate control of working hours in countries characterized by organized decentralization, if employees are well represented by unions at local level. This is the case in Denmark, where unions operate in an organized setting that supply employees with important local bargaining power. Three-quarters of employees in the private sector are covered by a collective agreement (DA, 2005), and around four out of five employees in Denmark are members of a trade union. Additionally, many employees are represented by on-site union representatives (shop stewards), who are allowed to conclude agreements with management: a recent survey found that four out of five manufacturing companies have shop stewards present. Even among smaller companies (20--49 employees), more than half have at least one shop steward on site (Ilsøe, 2009). The Danish system of shop stewards forms part of a long tradition of local pay negotiations that developed in the metal industry in the first half of the twentieth century and spread to other parts of the labour market 
(Due et al., 1994; Navrbjerg et al., 2001). There is an articulated system of multi-level collective bargaining, with sectoral agreements (every $2--4$ years in the metal industry) defining the framework for local negotiations at company level.

In Germany, bargaining decentralization is becoming increasingly disorganized, or as some define it, controlled, as the sectoral organizations (especially the unions) acquiesce in decentralization but seek to exert some control over developments at company level (Haipeter, 2009; Schulten, 2005). Hence there is greater union scepticism towards decentralization of working time regulation. Though the coverage of collective agreements remains high, at around 60 percent, the proportion has been falling significantly, as has union density which is now under 20 percent (Dribbusch, 2005b; Visser, 2006). Manufacturing workers (and public sector employees) are somewhat better organized than the average. However, high collective agreement coverage does not tell the whole story, since there has been a move from multiemployer towards single-employer bargaining as membership of employers' associations falls. Only about half of all private sector employees are now covered by sectoral agreements (Ellguth and Kohaut, 2010). Furthermore, sectoral agreements increasingly include 'opening clauses' which allow works councils or company-level union representatives to negotiate agreements which may in some circumstances derogate from the sectoral standard. While most larger companies have works councils, this is not the case in smaller private companies (Dribbusch, 2005b; Ellguth and Kohaut, 2005), and where they do exist they do not necessarily guarantee a union presence at the workplace. Union weakness at company level is illustrated by survey findings where more than four-fifths of works councillors report that decentralization has strengthened the position of the employer (Dribbusch, 2005b). The contrasting characteristics of decentralization in the three countries are set out in Table 2.

\section{Table 2. Three different forms of decentralization}

\begin{tabular}{|c|c|c|c|}
\hline $\begin{array}{l}\text { Coverage of } \\
\text { collective } \\
\text { agreements }\end{array}$ & $\begin{array}{l}\text { Union } \\
\text { density }\end{array}$ & $\begin{array}{l}\text { Presence of } \\
\text { workplace union } \\
\text { representatives }\end{array}$ & Type of decentralization \\
\hline
\end{tabular}

$\begin{array}{lllll}\text { Denmark } & \text { High } & \text { High } & \text { High } & \text { Organized } \\ \text { Germany } & \text { High/medium } & \text { Low } & \text { Uneven } & \text { Controlled } \\ \text { USA } & \text { Low } & \text { Very low } & \text { Low } & \text { Disorganized }\end{array}$




\section{Regulation of working hours in the Danish metal industry}

In Denmark the regulation of working hours has traditionally been exclusively a matter of collective bargaining. This principle was threatened by the 1993 EU Working Time Directive, which was initially implemented solely by collective agreement. After a threat of legal action by the European Commission, the Working Environment Act (Arbejdsmiljøloven) was amended to regulate the working time of those not covered by agreements.

In the metal industry, working hours for manual workers are regulated by the Industry Agreement (Industriens overenskomst); white-collar workers are covered by a separate collective agreement (Industriens funktionceroverenskomst), which has similar rules on working time. As well as the metal industry, both agreements cover a range of manufacturing industries represented by CO-industri, a 'cartel' of eight manufacturing trade unions, and $\mathrm{DI}$, the private sector employers' organization. The agreements prescribe a normal working week of 37 hours, which is also the case for most other sectors in Denmark.

The Industry Agreement offers wide scope for local negotiations on flexible working hours, on condition that a local shop steward is present and can reach an agreement with management on the issue. During the 1990s the options for local negotiations on selected forms of flexibility such as flexitime were expanded, and today it is possible to conclude local agreements on time accounts with reference periods of up to 12 months (Navrbjerg et al., 2001: 18). In 2000 a 'pilot scheme' was introduced, which made it possible to deviate completely from the chapter on working hours in the sectoral agreement. Initially, the use of this scheme required control and acceptance by the sectoral parties. However, these requirements were removed in 2004 and there is now only an obligation to inform the parties at sector level.

Today, the exact type of working-time flexibility applying at the workplace is typically negotiated at company level between management and shop stewards. Recent surveys show that 86 percent of manufacturing companies covered by the sectoral agreement have concluded one or more agreements on working hours, in half these cases involving flexitime. Most of these agreements (more than three-quarters) cover all or most employees at the workplace where they apply (Ilsøe, 2009: 53, 73).

Decentralized bargaining on working hours in Denmark dates back to the 1980s, when representatives of trade unions and employers' organizations in the industrial sector were faced by an increasing number of 'closet agreements' at company level. Both employers and employees felt a need to negotiate more flexible working hours, but their agreements were more or less concealed because the sectoral agreement did not allow much deviation on working time arrangements. Surveys from the mid-1990s suggested that one in four companies in the industrial sector had one or more closet agreements, and that a substantial proportion of these concerned local working hours arrangements (Navrbjerg et al., 2001: 26). In many ways, decentralization on working hours in Danish industry can therefore be said to have started from the bottom up. However, during the 1990s both unions and employers' organizations found an interest in agreeing on opening clauses that allowed negotiations on working hours at company level within the frame work of the sectoral agreement. According to a representative of DI, the opening clauses on working time secured 'orderly conditions' while still providing the flexibility wanted by employers (interview, DI, June 2005). Unions accepted this radical 
decentralization of working time regulation, as it proved possible at the same time to introduce supplementary benefits such as occupational pensions and extra holidays for everyone covered by the sectoral agreement (interview, CO-industri, June 2005).

Nevertheless, the primary reason why the unions could approve the decentralization of working time regulation was workers' strong bargaining power at company level (interview, CO-industri, June 2005), and this is still the case. This bargaining power is supported not only by high union density and high coverage of collective agreements, but also by a strong organization of shop stewards, who are elected by union members at the workplace and have extensive bargaining competence.

There is no doubt that the radical decentralization of collective bargaining on working time in Danish industry has contributed significantly to the prevalence of flexitime agreements at local level. Many employees are covered by such agreements and derive benefits from them. Both employers and shop stewards report a number of positive effects of these agreements, including increased satisfaction, easier recruitment of employees, improved work-life balance and social inclusion (Ilsøe, 2009: 71). This indicates that few straitjackets remain in the regulation of working hours in the Danish metal industry. Unions have not feared losing central control, as the high presence of shop stewards (even in smaller companies) supports workers' local bargaining power. It is difficult for employers to force employees to accept working time arrangements that do not at least partially satisfy their wishes. However, there is still a substantial proportion of companies (around sixty percent) without flexitime agreements. Many of these might have informal flexitime arrangements, as was the case in many companies in the 1980s, but we do not know how many and with what effects. Furthermore, agreements on flexitime do not seem to be accessible to all groups of employees, as roughly a quarter of the agreements do not cover all employees at the workplace.

In conclusion, the regulation of working time in the Danish metal industry can be described as a comprehensive but also incomplete regulation, leaving considerable room for manoeuvre at company level. Unions neither perceive the regulation as a straitjacket nor as a safety net. Instead, they stress the importance of their own local bargaining power. Employees are well represented by unions in most companies because of high density levels and an extensive presence of shop stewards. Unions therefore feel generally confident that local negotiations on working hours are to the benefit not only of employers but also employees.

\section{Regulation of working hours in the German metal industry}

German regulation of working time involves a mixture of legislation and sectoral agreements. According to the Arbeitszeitgesetz (Working Time Act), a working day should not normally exceed eight hours, but may be extended to ten hours if the average working day over six months is kept within eight hours. However, the act allows unions and employers' organizations at sector level to agree on a different reference period (12 or 24 months), as long as the hours worked do not breach the rule of 11 unbroken hours of rest per day or the maximum of 48 weekly working hours prescribed in the EU Working Time Directive. 
Sectoral bargaining in the German metal industry takes place in seven different regions (Bezirke), where separate collective agreements are concluded. Consequently, the sectoral trade union and the employers' organization coordinate horizontally to ensure homogeneity of agreements in the different regions. Typically a trend-setting 'pilot' agreement is concluded in Baden-Württemberg or Nordrhein-Westfalen, and is then copied in the other regions. This is also the case regarding working time regulations. An important exception is that normal working hours are $35 \mathrm{a}$ week in the western Germany and 37 in the east.

There are three significant collective agreements on working time in BadenWürttemberg. First, the basic framework agreement in the industry (Manteltarifvertrag für Beschäftigte) allows negotiations on flexible working hours with a reference period of six months; surplus hours can be taken as time off in lieu. This opening clause makes it possible for local works councils and management to negotiate works agreements (Betriebsvereinbarungen) on flexible hours within certain limits. Second, the 'Pforzheim agreement' signed in March 2004 and extended in 2008 as the Tarifvertrag zur Beschäftigungssicherung und zum Beschäftigungsaufbau (agreement for protecting and increasing employment) made it possible to deviate more radically from the framework agreement including all aspects of working hours. This enabled company agreements that go beyond the text of the sectoral agreement (Ergänzungstarifverträge), and similar clauses were rapidly agreed in the other bargaining regions. However, resort to the Pforzheim agreement requires approval by the regional offices of the bargaining parties, IG Metall and Gesamtmetall, who also participate in the bargaining process together with the works councils. Third, in February 2005 the bargaining parties signed the Tarifvertrag zur Änderung der Manteltarifverträge und der Tarifverträge zur

Beschäftigungssicherung in Baden-Württemberg, reformulating part of the framework agreement on working hours. The primary aim was to address the regulation of flexible working time as a mechanism to safeguard jobs and avoiding unnecessary hiring and firing. This reformulation was unique in that it was the first agreement in Germany to allow negotiations on working time accounts with no obligatory reference period. However, it stated that the company bargainers had to agree an upper and lower limit on the time accounts instead.

A survey of works councillors in the German private sector, undertaken by the unionlinked Wirtschafts- und Sozialwissenschaftliches Institut (WSI), suggests that these and similar opening clauses on working hours have been widely used, as nearly half of the companies covered by collective agreements have reached accords on flexible working time arrangements (Dribbusch, 2005a). This figure includes agreements on both flexitime and on annualized hours. However, interviews at the local IG Metall office in Baden-Württemberg and the head office in Frankfurt (May and June 2005) indicated that the union has been sceptical about decentralization of working hours and insists on controlling the application of the Pforzheim Agreement. The union has in general been reluctant to devolve bargaining competencies and has only agreed to decentralization of working time regulation in order to retain a minimum of control over developments at company level: during the late 1980s and early 1990s, companylevel deviation from sectoral agreements on working hours spread across the industry, and there was relatively little the union could do to prevent this. This became even more difficult during the 1990s, where growing signs of erosion within the German collective bargaining system were leaving workers with less bargaining power at company level than before (Hassel, 1999). 
In spite of the extensive options for local negotiations on working time flexibility, many employers still see the regulation of working hours as too rigid (interview with representative of Südwestmetall, June 2005). In a survey of members of the employers' organizations in the metal industry, more than half of small and medium-sized companies expressed dissatisfaction with these regulations (Behrens, 2002). However, working hours might not be the real reason for dissatisfaction. Wage-setting in the German metal industry is first and foremost a matter of sectoral bargaining, and has not been decentralized in the same way as working time scheduling. It can therefore be argued that the argument over working time regulation is a disguised attack on centralized wage determination. Although the Pforzheim Agreement made it possible for employers to reduce labour costs, for instance by increasing working hours without wage compensation, it is mainly larger companies that have succeeded in concluding such arrangements with the unions (Gesamtmetall, 2005; Seifert and Massa-Wirth, 2005). From a union perspective, the price of fewer straitjackets on working hours might be a less efficient safety net on wages, and they are therefore willing to accept deviations on working hours that affect pay levels, primarily because larger numbers of workplaces are at risk.

Summing up, the regulation of working hours in the German metal industry is quite detailed with both substantive legislation and sectoral agreements. However, the extensive possibilities for local negotiations make regulation rather incomplete and few straitjackets on working hours should therefore remain. However, employers still express a wish of further decentralization that unions reject. One reason to this could be that the regulation of working hours in practice works as a safety net on pay, helping unions protect low-wage workers. Unions might fear that further decentralization of working time regulation would result in even lower pay levels for this group of workers.

\section{Regulation of working hours in the American metal industry}

In the USA, working hours are regulated by the 1938 Fair Labor Standards Act (FLSA), which limits standard weekly working hours to 40 . All hours exceeding this limit must be paid as overtime (at time-and-a-half). This means that employers have little interest in introducing flexible working hours that goes beyond the standard work week; they prefer the use of regular overtime rather than paying overtime rates for working time flexibility, and bargaining options for employees on flexitime (which is termed 'comp time' in the USA) are therefore limited (Golden and Jorgensen, 2002; Jacobs and Gerson, 2000). As the FLSA is national legislation, the 40-hour rule applies to the metal industry, manufacturing in general and most other private and public industries. Exemptions are few and include certain forms of work like executive functions and certain industries like farming and fishing.

Polls have indicated that many employees request more flexible working hours than is currently possible, in order to combine work and family life more effectively (Golden, 2003: 2; Walsh, 1999: 86). However, it is employers, not unions, who have argued for reforms of the FLSA. Since the mid-1990s a number of Republican members of Congress have proposed amendments that would give employers easier access to implementing flexible working hours. Many of these amendments would facilitate the introduction of comp time for private sector 
employees. Instead of employers paying overtime rates for hours above 40 per week, it is suggested that these hours should be banked at overtime rates, allowing employees to take an hour and a half hours off in lieu for each excess hour worked (Felder, 2005: 279-80; Vance, 2002: 316-7). These amendments are inspired by the options in the public sector, where supplementary legislation (Federal Employees Flexible and Compressed Work Schedules Act, FEFCWA, 1978) allows federal employees greater scope for working time flexibility. The Act introduced two forms of working time flexibility: comp time, where employees can bank up to 24 hours over a two-week period to take as time off in lieu in the following two weeks (with no supplementation); and compressed work schedules, which allows 80 working hours to be distributed across fewer than 10 working days within a two-week period. This latter option can be used for instance to create work weeks of four ten-hour days.

I conducted interviews with a lawyer who has represented many employers in legal cases on working hours (June 2007), and with a representative of the National Association of Manufacturers (July 2007), a large lobbying group for manufacturing employers. Employer arguments for introducing comp time have been many, but most pronounced are those for greater scope to offer employees family-friendly working hours (Vance, 2002: 316; Walsh, 1999: 84-5). Female labour market participation has increased dramatically since the FLSA was introduced in 1938, and employers are interested in offering family-friendly working schedules to recruit and retain female workers and male workers from dual-career families with children. Others argue for more flexible scheduling of hours to adjust to new forms of work organization involving flat hierarchies and team work (Walsh, 1999; Wilson, 2001). Finally, some private employers address the issue of FLSA and costs, arguing that comp time would make it possible to reduce overtime payments (Walsh, 1999: 87).

Academics, as well as unions, have been more sceptical towards the introduction of comp time for private sector employees. First of all, empirical evidence suggests that it is already possible to negotiate a number of flexible working time arrangements under the current legislation without imposing costly overtime payments on employers. This includes collective agreements on comp time within the working day or week, compressed work weeks and the socalled 80/9 schedule, which provides for eight nine-hours days and one eight-hour day followed by a three-day weekend every fortnight (Golden, 2003: 1; Ilsøe, 2008: 46-7; Walsh, 1999: 912). Furthermore, evaluations of the FEFCWA in the public sector have reported not only positive effects such as improved work-life balances, easier recruitment, increased employee satisfaction and reduced absence, but also about important problems (GAO, 2002). Academics have addressed two areas of concern in particular. First, public employees often bank surplus hours that they are never able to take as time off in lieu, which means that comp time is not necessarily more family friendly than overtime. Second, and perhaps explaining the first problem, public employees are not granted more control over the timing of hours than under the FLSA (which allow employers to dictate overtime work), and this can form a barrier to the reconciliation of work and family life (Golden, 2003: 4; Walsh, 1999: 110-1).

Many argue that this lack of control will have severe consequences if comp time is introduced to the private sector, where union density is substantially lower than the 36 percent found in the public sector. Although workers in manufacturing are slightly better organized than in the private sector in general (12 percent compared to 8 percent), this still leaves them with little voice over working time issues in relation to management. Case studies have underlined 
that union representation is of key importance if the introduction of flexible working hours is to improve employees' work-life balance (Gerstel and Clawson, 2001; Bigler, 2002). The FLSA does not grant workers a right to refuse overtime working, but unionized workers are more likely to have a contract that establishes rules for requesting overtime. Conversely, if union presence at a company is low or non-existent, it is more likely that management will dictate rather than negotiate the flexibility needed. The risk that banked hours are left unused (and unpaid) is therefore much higher in the private than in the public sector (Golden, 2003: 1-6; Walsh, 1999: 126-7).

I discussed the implications of introducing comp time in the private sector in interviews with a representative of the International Association of Machinists and Aerospace Workers (IAM) in May 2007 and separately with two representatives of the AFL-CIO in June 2007. They indicated that their primary concern is not how the lack of control will affect the scheduling of working hours, but rather that an amendment to the FLSA will affect the income of working families and the creation of full-time jobs (AFL-CIO, 2007). As real wages for US workers have been falling over the past decades, many of them depend heavily on overtime pay (Mishel et al., 2007). About a quarter of employees in manufacturing work more than 50 hours per week, and overtime pay therefore forms a substantial part of their monthly income (Golden and Jorgensen, 2002: 6). It has therefore been suggested that any reform of the FLSA should include an hourly wage threshold for eligibility for comp time. Such a threshold would make it possible to allow comp time for those workers who can afford it, and protect those workers who cannot (Felder, 2005). However, this would not necessarily solve the question of control over the scheduling of hours. Workers with wages above the hourly threshold could still be forced into working surplus hours that they never get the chance to take as time off in lieu, as many of them are not unionized. Furthermore, such a reform could still have a negative impact on the number of workplaces. Unions still highlight that one of the main targets of the FLSA was the creation of new jobs. The 40-hour limit was set in order to encourage employers to open new full-time positions rather than to solve staffing problems through excessive use of overtime hours. If this limit is removed or changed, unions believe it will have a negative effect on job creation (AFL-CIO, 2007).

In conclusion it can be said that although the content of the FLSA is simple and not very detailed, it still stands out as a complete regulation with regards to working hours in the metal industry (and most others parts of the private sector). It does not allow deviations to be negotiated at local level, and polls suggest that many employees see the current FLSA regulation as a 'straitjacket' which frustrates their wishes for family-friendly working hours. We also find employers who would like to introduce comp time to attract employees with small children, as they find this difficult under the current regulation. However, unions primarily see the FLSA as one of the few remaining 'safety nets' to secure jobs and income levels among working families in the private sector. Low union density makes it extremely difficult for unions to negotiate higher wages and contribute to job creation in other ways, and therefore they still see the FLSA as an important protection for employee rights. The question is, of course, whether this represents the view of all employees. It might well be those employees who earn the most who express a wish of more flexibility, whereas low-wage workers have their primary focus on the effects on pay. 


\section{Comparative analysis}

Today, employees in many countries desire more flexible working hours that would facilitate a better balance between work and family life. However, surveys show that access to flexible work-time arrangements varies significantly across countries. This is the case when comparing manufacturing workers (including those in the metal industry) in Denmark, Germany and the USA. Around half the Danish and German workers report such access, but only one in four of American workers. An important explanation for this variation is the different processes of decentralization in these three countries. This is reflected in union responses to employees' desires for working-time flexibility and in the content of the regulatory frameworks on working time at national or sectoral level, which leave Danish and German metal workers with the largest room for manoeuvre in local negotiations on working hours. Under the FLSA, American workers are faced with a tighter 'straitjacket' constraining their possible wishes for workingtime flexibility. Nevertheless, not only American but also German unions are concerned that the regulation on working hours at central levels should provide a 'safety net' for workers, whereas this appears less important to Danish unions.

The Danish metal industry is characterized by high union densities, high coverage of collective agreements and a wide presence of shop stewards. In this setting of organized decentralization, unions have agreed on a strong devolution of bargaining competencies over flexible working hours from the sectoral to the company level. A number of opening clauses have been introduced in the sectoral agreement, and there is no demand for approval of company agreements by the parties at sector level. Surveys have shown that the large room for manoeuvre at company level has been to the benefit of many employees, in both larger and smaller companies. Although regulation is quite detailed, few straitjackets remain, and unions feel confident that managers and employees are able to negotiate balanced agreements on flexitime. However, it should be mentioned that a substantial group of companies has not concluded such agreements. Furthermore, agreements do not always cover all employees at the workplace, and some employees might therefore still experience 'straitjackets' with regard to the regulation of their own working hours.

In the German case, bargaining competencies on flexible working hours have been delegated both from national legislation (the Arbeitszeitgesetz) and from sectoral agreements to the company level through opening clauses. The regulation of working time is very detailed, but it also contains a wide range of options for local negotiations that render it incomplete in character. However, as union density and the presence of works councils among SMEs have been declining over the past decades, unions have been cautious to give up control over the regulation of working time at company level. The situation in Germany can be characterized as controlled decentralization, where the use of a number of opening clauses still requires approval from the sector bargaining parties. The effect is fewer regulatory 'straitjackets' but mainly for employees at larger companies, where works councils are present and unions are more willing to accept local negotiations.

In the American metal industry, low union densities, poor coverage of collective agreements and little presence of union representatives make if difficult for employees to 
articulate their needs because of limited bargaining power. In this environment of disorganized decentralization, only minorities of workers have access to flexible working hours. Unions have opposed a suggested reform of the national legislation on working time, the FLSA, that could make it more attractive for employers to introduce working time flexibility. The reform would, within certain limits, allow local negotiations on working hours and thereby make the content of the FLSA less complete. However, unions fear that a reform will cause a significant loss in income among workers, and discourage employers from creating new jobs. Even though polls suggest that the FLSA imposes a 'straitjacket' on employees' desire for more family-friendly working hours, unions are not willing to pay the price of losing an important 'safety net' with regard to the income levels of working families and job creation.

This comparative analysis of the regulatory frameworks on working hours has shown that one aspect is of decisive importance when it comes to determining whether regulation serves as a straitjacket or a safety net: union power at local level. If workers are not organized and well represented by unions at their workplace, unions will be unlikely to see decentralization as a mechanism which can improve employees' choice of their own working hours. In other words, they do not considerable it possible to abandon the straitjacket without losing important safety nets at the same time. This is true for the American metal industry, where unions oppose the loss of the straitjacket of the not very detailed regulation on working hours of the FLSA. Conversely, if workers are organized and covered by agreements and local union representatives, unions are more willing to introduce opening clauses to the legislation and sectoral agreements, so as to allow working hours to be negotiated at company level. In these cases, unions can see decentralization as an option for adjusting working hours to the needs of employees, and they are willing to abandon the straitjacket of regulation at central levels. Such a development can be observed in the Danish and, to some extent, the German metal industries.

Straitjackets and safety nets on working hours seem to coexist with, not replace, one another. The comparative analysis indicates that unions are more willing to let go of straitjackets on working hours where safety nets are less necessary (in other words, where unions have a strong platform at company level). This also includes safety nets on pay, to which we turn in the final section.

\section{Discussion and conclusion}

Flexible working hours --- and especially flexitime --- are often considered a 'soft' issue in collective bargaining, as flexible working hours can help to improve employees' work-life balance or their so-called combination security (Wilthagen, 2002). But the organization of working time can be a 'hard' issue in reality. Both the American and German cases suggest that the question of working hours is closely related to those of pay and employment levels (pay flexibility and job security). This means that losing 'straitjackets' on working time might result in the loss of important 'safety nets' in other areas. Among other problems, a decentralization of the regulation of working hours can entail greater decentralization of wage determination. In a context of falling union density this can make unions fear that employers will surreptitiously 
impose lower wages through the back door of more flexible working hours. This is the case in Germany, where unions at sector level want to control the mainly local organization of working hours to sustain centralized wage determination. The situation in the USA is to some extent the reverse, but for the same reasons. Here, unions seek to keep the regulation of working hours at central level to compensate workers for unsustainable pay levels regulated at local level. It remains an open question whether this fear of further decentralization among unions in Germany and the USA is based on sound evidence or just expectations. Surveys from different sectors in the UK have indicated that decentralization of collective bargaining on pay and working time does not lead to greater pay inequality (Arrowsmith and Sisson, 1999).

Both the German and American stories tell us that the level of regulation of working hours is of great importance to unions, when union density is low. However, this first and foremost has to do with the potential impact of the decentralization of working hours on pay levels. Only in the Danish case, where union density remains high and most companies have shop stewards present, have unions been willing to accept a radical decentralization of bargaining on both pay and working hours. These two elements of organized decentralization, high union densities and presence of on-site union representatives, therefore seem to be important preconditions for unions to give up control and for employees to lose national or sectoral 'straitjackets' over working time. Not only because they supply employees with local bargaining power over working hours, but also, and perhaps more importantly, because they supply employees with local bargaining power over pay.

To add complexity, the analysis of the American and German cases suggests that such interaction between working-time flexibility and pay flexibility (and probably also job security) is unevenly distributed among employees. Workers in companies with pay levels above average who feel secure about their jobs might be interested in negotiating flexible working hours, whereas working-time flexibility can be a threat to workers on low wages and with a fear of job loss. The first group might see the national regulation of working hours as straitjackets, while the second group might value the safety net that such regulation gives them in respect to pay. However, this difference of interest does not necessarily follow the line between 'insiders' (organized and skilled workers) and 'outsiders' (unorganized and unskilled workers) (Atkinson, 1987; Dobbie, 2006; Lindbeck and Snower, 2001). The analysis indicates that we also find differences within the group of insiders, and unions are faced with the challenge of representing diverse interests on working hours among organized workers.

\section{Acknowledgements}

I am grateful to my colleagues Steen E. Navrbjerg and Trine P. Larsen for valuable comments on earlier versions of this article. Many thanks also to the anonymous referees and the Editor. 


\section{References}

AFL-CIO (2007) FLSA Rollbacks. Washington: AFL-CIO.

Arrowsmith J (2007) Why is there not more 'annualised hours' working in Britain?. Industrial Relations Journal 38(5): 423--38.

Arrowsmith J and Sisson K (1999) Pay and Working Time: Towards Organization-based Systems? British Journal of Industrial Relations 37 (1): 51--75.

Atkinson J (1987) Flexibility or fragmentation? The United Kingdom labour market in the eighties. Labour and Society 12(1): 87--105.

Behrens M (2002) New Study analyses development of employers' associations. Dublin: Eurofound. http://www.eurofound.europa.eu/eiro/2002/12/feature/de0212202f.htm

Berg P, Appelbaum E, Bailey T and Kalleberg AL (2004) Contesting Time: International Comparisons of Employee Control of Working Time. Industrial and Labor Relations Review 75(3): 331--49.

Bigler R (2002) Unions Give Workers the Power to Fight Forced Overtime. New York: Labor Research Association.

BLS (2005a) Workers on Flexible and Shift Schedules in May 2004. Washington: Bureau of Labor Statistics.

BLS (2005b) Union members in 2004. Washington: Bureau of Labor Statistics.

Bosch G (2001) Working time: From redistribution to modernization. In: Auer P (ed) Changing labour markets in Europe. The role of institutions and policies. Geneva: ILO, 55--115.

DA (2005) Arbejdsmarkedsrapport. Copenhagen: DA.

Dobbie M (2006): Insider Power, Outsider Ineffectiveness and Wage Setting Institutions: Evidence from Australia. Australian Bulletin of Labour 32 (4): 421--449.

Dribbusch H (2005a) New Survey Findings on Works Councils and Decentralisation of Bargaining. Dublin: Eurofound. http://www.eurofound.europa.eu/eiro/2005/10/feature/de0510202f.htm

Dribbusch H (2005b) New data on coverage of collective agreements and works councils. Dublin: Eurofound. http://www.eurofound.europa.eu/eiro/2005/09/feature/de0509205f.htm

Deding M, Lausten M and Andersen A (2006) Børnefamiliers balance mellem familie- og arbejdsliv. Research Report 06:32. Copenhagen: Det Nationale Forskningscenter for Velfærd.

Due J, Madsen JS and Jensen CS (1994) The Survival of the Danish Model. Copenhagen: DJØF Publishing.

Ellguth P and Kohaut S (2005) Tarifbindung und betriebliche Interessenvertretung - Aktuelle Ergebnisse aus dem IAB-Betriebspanel. WSI-Mitteilungen 58(7): 398-403.

Ellguth P and Kohaut S (2010) Tarifbindung und betriebliche Interessenvertretung - Aktuelle Ergebnisse aus dem IAB-Betriebspanel 2009. WSI-Mitteilungen 63(4): 204-9.

Felder M (2005) Not Quite 'Family Friendly': Amending the Fair Labor Standards Act to Provide Comp Time May Hurt Welfare Leavers and Their Families. Georgetown Journal on Poverty Law \& Policy 12(2): 273--98. 
GAO (2002) Human Capital: Effective Use of Flexibilities Can Assist Agencies in Managing Their Workforces. Washington: General Accounting Office.

Gerstel N and Clawson D (2001) Unions' Responses to Family Concerns. Social Problems 48(2): 277--97.

Gesamtmetall (2005) Der moderne Flächentarifvertrag in der M+E-Industrie. Berlin: Gesamtmetall.

Golden L (2001) Flexible work schedules: Which workers get them?. American Behavioral Scientist 44(7): 1157--78.

Golden L and Jorgensen H (2002) Time After Time. Mandatory overtime in the US economy. Washington: Economic Policy Institute.

Golden L (2003) Comp time bills off target. EPI Briefing Paper 135. Washington: EPI.

Haipeter T (2008) Konflikte stärken die Partnerschaft. Magazin Mitbestimmung 10: 26-9.

Haipeter T (2009) Kontrollierte Dezentralisierung? Abweichende Tarifvereinbarungen in der Metall- und Elektroindustrie. Industrielle Beziehungen 16(3): 232--53.

Hassel A (1999) The Erosion of the German System of Industrial Relations. British Journal of Industrial Relations 37(3): 483-505.

Ilsøe A (2008): Trade-offs on Flexible Working Hours at the Company Level: Case Studies from Denmark and the United States. In: Eaton AE (ed.) Proceedings of the 60th Annual Meeting. Champaign, Illinois: LERA, 42--50.

Ilsøe A (2009) Decentralisering i praksis. FAOS Research Paper No 103. Copenhagen: Københavns Universitet.

Ilsøe A (2010) Between trust and control: company-level bargaining on flexible working hours in the Danish and German metal industries. Industrial Relations Journal 41(1): 34--51.

Jacobs JA and Gerson K (2000) Who are the overworked Americans? In Golden L and Figart DM (eds) Working Time. International Trends, Theory and Policy Perspectives. London: Routledge.

Katz HC (1993) The Decentralization of Collective Bargaining: A Literature Review and Comparative Analysis. Industrial and Labor Relations Review 47(1): 3--22.

Lewis S and Dulk LD (2010) Parents' experiences of flexible work arrangements in changing European workplaces. In Christensen K and Schneider B (eds.) Workplace Flexibility: Realigning 20th Century Jobs to 21st Century Workers. Ithaca: Cornell University Press.

Lindbeck A and Snower DJ (2001) Insiders versus Outsiders. Journal of Economic Perspectives 15(1): 165--88.

Marginson P and Sisson K (2004) Working time patterns: Confirming the significance of the sector. In: Marginson P and Sisson K (eds) European integration and industrial relations. Multi-level governance in the making. Basingstoke: Palgrave Macmillan, 271-88 .

Mishel L, Bernstein J and Allegretto S (2007) The State of Working America. Ithaca: Cornell University Press.

Navrbjerg SE, Nordestgaard M and Due J (2001) Fremtidens overenskomster $i$ decentraliseringens tegn. Copenhagen: $\mathrm{CO}$-industri. 
Presser HB (2006) Employment in a 24/7 economy: challenges for the family. In: Perrons D, Fagan C, McDowell L, Ray K and Ward K (eds) Gender Divisions and Working Time in the New Economy. Cheltenham: Edward Elgar, 35--57.

Schulten T (2005) Changes in national collective bargaining systems since 1990. Dublin: Eurofound. http://eurofound.europa.eu/eiro/2005/03/study/tn0503102s.htm

Seifert H (2005) Arbeitszeitpolitischer Modellwechsel: Von der Normalarbeitszeit zu kontrollierter Flexibilität. In: Seifert H (ed.) Flexible Zeiten in der Arbeitswelt. Frankfurt: Campus Verlag, 40--66.

Seifert H and Massa-Wirth H (2005) Pacts for Employment and Competitiveness in Germany. Industrial Relations Journal 36 (3): 217-40.

Traxler F (1995) Farewell to labour market associations? Organized versus disorganized decentralisation as a map for industrial relations. In: Crouch C and Traxler F (eds) Organized Industrial Relations in Europe: What Future?. Aldershot: Avebury, 3--19.

Vance S (2002) Trying to Give Private Sector Employees a Break: Congress's Efforts to Amend the FLSA. Hofstra Labor and Employment Law Journal 19(2): 311--49.

Visser J (2006) Union Membership Statistics in 24 Countries. Monthly Labor Review 129(1): 38-49.

Walsh DJ (1999) The FLSA comp time controversy: Fostering flexibility or diminishing worker rights?. Berkeley Journal of Employment and Labor Law 20(1): 74--137.

Wilson M (2001) Modernizing the Fair Labor Standards Act for the 21 st Century. Washington: Heritage Foundation.

Wilthagen T (2002) The Flexibility-security nexus: New approaches to regulating employment and labour markets. Paper for the British Journal of Industrial Relations Conference 'The Politics of Employment Relations`. Tilburg: OSA. 